\title{
Educating for Peace: The Role and Impact of International Organisations in Interwar and Post-War Danish School Experiments, 1918-1975
}

\author{
Karen Egedal Andreasen \\ Christian Ydesen
}

\begin{abstract}
In the aftermath of the two world wars, strong international networks and organisations manifested themselves with promotion of peace through education on their agenda. Danish pedagogical experiments and experimental schools were strongly influenced by these trends and played a role in subsequent school practices and policies. Drawing on the notions of "the transnational" and "trading spaces" as well as the theoretical concepts of transfer, translation, and transformation, this article addresses the following research question: How were international ideas, knowledge and practice of promoting peace through education transferred, translated, and transformed in Danish school experiments in interwar and post-war scenarios? In exploring this question, the article uses transnational and Danish archival sources as well as journals and reports linked to the Danish progressive education movement. Thus, the article contributes to our understanding of the entanglements of educational ideas and to how trends of internationalisation and globalisation work.
\end{abstract}

Keywords

education for peace, school experiments, progressive education, international organisations, Danish education

\section{Introduction}

During the ten years the League of Nations has existed, it has in many ways endeavoured to secure peace between the states, but those who work for the idea of the League know that real security will be reached only when a moral disarmament, a mental disarmament, is achieved. The nature of the relations among the three Nordic countries is such that everybody takes it for granted that war between any of them is impossible. A similar feeling should be created among all peoples. ${ }^{1}$

Danish Minister of Foreign Affairs, Peter Munch (1870-1948), in 1929

The years following the two world wars were characterised by reflections on how to prevent wars in general and the role of education in particular in securing such a political aim. Education was seen as a privileged field of intervention because of its

1 "Kronborg Magazine - Fifth International Conference on New Education," August 1929, Elsinore, Denmark, World Education Fellowship, III/186, Institute of Education London Archives, 27. Our translation.

Karen Egedal Andreasen is Associate Professor in Pedagogy at the Department of Learning and Philosophy, Aalborg University, Denmark.

Email: karena@learning.aau.dk

Christian Ydesen is Associate Professor in Educational Science at the Department of Learning and Philosophy, Aalborg University, Denmark.

Email: cy@learning.aau.dk 
potential to support social equity and stable economies, prevent social conflicts and promote international understanding. ${ }^{2}$

As has been argued recently, this view sparked an internationalisation of education as well as an extensive interest in progressive education initiatives. ${ }^{3}$ Thus, several theorists, practitioners, and politicians across the Western world shared this reformist agenda and its explicit ideas about securing peace in the future through education. The key idea was that education combined with social welfare for children would be a precursor for building peace and international reconciliation. ${ }^{4}$

After the two world wars, these ideas were introduced in school experiments in the Danish public school system (Folkeskolen) and implied reflections on both education policy and pedagogy in terms of using education to create social stability and peace at home and prevent wars between nations. Most of these school experiments aiming to implement and domesticate these internationally anchored ideas in terms of policy and educational practice were launched by educators and politicians associated with the international progressive education movement. ${ }^{5}$

Educational experiments took place in numerous countries in the interwar and post-war periods. The worldwide experiments and their dominant ideas and practices were highly inspired by cooperation in different international fora, especially The International Committee on Intellectual Cooperation (ICIC) under the auspices of the League of Nations, the New Education Fellowship (NEF) and - after 1946 - the United Nations Educational, Scientific and Cultural Organization (UNESCO). ${ }^{6}$ Further can be mentioned cooperation in organisations such as the Council of Europe established 1949 and from 1961 the OECD and two of its sub-organisations: The Centre for Educational Research and Innovation (CERI), established in 1968, and International Movement Towards Educational Change (IMTEC), established 1972. Despite their importance in the evolvement of Danish public school experiments, these links and inspirations remain somewhat absent from the existing historio-

2 Ian Harris, "History of Peace Education," Encyclopaedia of Peace Education (Charlotte: Information Age Publishing, 2008), 15-24; Herbert Read, Education for Peace (New York: Charles Scribner's, 1949); Zoe Moody, “Transnational Treaties on Children's Rights: Norm Building and Circulation in the Twentieth Century," Paedagogica Historica 50, nos. 1-2 (2014), 151-64.

3 See e.g. Henrik Åström Elmersjö, “The Norden Associations and International Efforts to Change History Education, 1919-1970: International Organisations, Education, and Hegemonic Nationalism," Paedagogica Historica 51, no 6 (2015), 727-43.

4 Joelle Droux, "Children and Youth: A Central Cause in the Circulatory Mechanisms of the League of Nations (1919-1939)," Prospects 45, no. 1 (2015), 6376; Ingela Nilsson, Nationalism i fredens tjänst: Svenska skolornas fredsförening, fredsfostran och historieundervisning 1919-1939 (Umeå: Umeå universitet, 2015).

5 Ellen Nørgaard, Lille barn, hvis er du? En skolehistorisk undersøgelse over reformbestrcebelser inden for den danske folkeskole i mellemkrigstiden [Little Child, Whose Are You? A History of Education Inquiry into Reform Movements Within the Danish Folkeskole in the Interwar Years] (Copenhagen: Gyldendals Pædagogiske Bibliotek, 1977); Christian Ydesen, The Rise of High-Stakes Educational Testing in Denmark, 1920-1970 (Frankfurt: Peter Lang Verlag, 2011). In Denmark the international progressive education movement was manifested in the so-called "progressive education movement" (den reformpoedagogiske bevogelse).

6 Emily Hermon, "Peace Education Between the World Wars: A Historical Overview Of The Organized Transnational Peace Education Movement," Peace Research 19, no. 2 (1987), 2-6, 75-78; Harry J. Krould and Helen F. Conover, Textbooks Their Examination and Improvement: A Report on International and National Planning and Studies (Washington: The Library of Congress, 1948); Jan Kolasa, International Intellectual Cooperation: The League Experience and the Beginnings of UNESCO (Wroclaw: Polskij Akademii, 1962); Joseph A. Lauwerys, History Textbooks and International Understanding: Towards World Understanding (Paris: UNESCO, 1953). 
graphy of Danish education. Some of the few exceptions are two PhD dissertations written by Karen Gram-Skjoldager and Poul Duedahl. Gram-Skjoldager treats the relations between Denmark and the League of Nations and the movement's focus on promoting peace through an intellectual, international fight against militarism via conferences, information and education. ${ }^{7}$ Duedahl traces the links with UNESCO's education for international understanding and Danish textbook revision initiatives and educational circulars. ${ }^{8}$ However, they do not discuss the links and connections between the Danish progressive education movement and the international ditto or the domestication of international education for peace initiatives as manifested in Danish school experiments.

This article focuses on "trading spaces" where ideas, knowledge and practices are exchanged, and on related travel routes into Danish school experiments where they might have influenced both policy and practice. Thus, the article sheds light on 1) the workings of "the transnational" in history of education research; 2) how ideas, knowledge and practices travel and influence local (national) educational contexts; and 3) what sort of international impact can be discerned in terms of Danish education for peace initiatives.

\section{Methodology and research question}

Methodologically the article draws on the notion of "the transnational" in history of education research ${ }^{9}$ and the theoretical concepts of transfer, translation, and transformation put forth by Robert Cowen, Professor Emeritus of Comparative Education. ${ }^{10}$ Subscribing to the transnational turn in history of education research is an attempt to transcend the trammels of methodological nationalism with its "one nation - one school" narrative. Such a framework allows us to trace transnational spaces in which ideas, knowledge, and even practices can move beyond the national frame of reference, and to understand the cross-border entanglements which function as precursors and/or facilitators and/or sources of influence of national and local developments. However, as pointed out by geographer David Livingstone, meaning is always constructed locally. New ideas, knowledge and practices simply have to make sense in the receiving context to become viable. ${ }^{11}$ Therefore the perspectives of space and place must be understood as intimately connected. ${ }^{12}$

7 Karen Gram-Skjoldager, Fred og folkeret: Dansk internationalistisk udenrigspolitik 1899-1939 (Copenhagen: Museum Tusculanums Forlag, 2012), 62-63.

8 Poul Duedahl, Fra overmenneske til UNESCO-menneske: En begrebshistorisk analyse af overgangen fra et biologisk til et kulturelt forankret menneskesyn i det 20. århundrede ( $\mathrm{PhD}$ dissertation, Institut for Historie, Internationale Studier og Samfundsforhold Aalborg Universitet, 2007), $231 \mathrm{ff}$.

9 Thomas S. Popkewitz, ed., Rethinking the History of Education: Transnational Perspectives on its Questions, Methods, and Knowledge (New York: Palgrave Macmillan, 2013); Eckhardt Fuchs, "History of Education beyond the Nation? Trends in Historical and Educational Scholarship," in Connecting Histories of Education: Transnational and Cross-Cultural Exchanges on (Post-)Colonial Education, ed. Barnita Bagchi, Eckhardt Fuchs, and Kate Rousmaniere (New York: Berghahn Books, 2014), 11-26.

10 Robert Cowen, "Acting Comparatively upon the Educational World: Puzzles and Possibilities," Oxford Review of Education 32 (2006), 561-73.

11 David Livingstone, Putting Science in its Place: Geographies of Scientific Knowledge (Chicago: University of Chicago Press, 2003), 88.

12 Ivan Lind Christensen and Christian Ydesen, "Routes of Knowledge: Towards a Methodological Framework for Tracing the Historical Impact of International Organizations," European Education 47 , no. 3 (2015), 274-88. 
As analytical concepts for working with such transnational "trading spaces" and the routes leading from the transnational space to the local practice, the concepts of transfer, translation, and transformation are feasible because they provide the opportunity to discern and understand the movements and travels of ideas, knowledge and practices. Cowen defines the concepts as follows: ${ }^{13}$

a) transfer is the movement of an educational idea or practice in supra-national or transnational or international space: the "space-gate" moment, with its politics of attraction and so on;

b) translation is the shape-shifting of educational institutions or the re-interpretation of educational ideas which routinely occurs with the transfer in space: "the chameleon process"; and

c) transformations are the metamorphoses which the compression of social and economic power into education in the new context imposes on the initial translation: that is, a range of transformations which cover both the indigenisation and the extinction of the translated form.

Following Noah Sobe's critique of "transfer paradigms", we do not suggest the existence of fixed points of departure and arrival when treating the travelling ideas, knowledge and practices. ${ }^{14}$ Rather, we introduce the concept of "trading spaces" meaning places of encounters where "dense webs of relationships", entanglements, and negotiations happen. Identifying relevant trading spaces is an empirical question, and once they have been identified it is possible to empirically trace changes in terms of concepts, discourse and concrete practices in the local context; in this case school experiments. This is precisely where Cowen's concepts can be put to good use.

However, according to Cowen's definition, the key forces in the transformation process are the "social and economic power" of the context of reception; that is, social and economic power determines the fate of the moving idea, knowledge, or practice. This line of thought in combination with our proposed analytical focus on discourse, concept, and practice opens the analytical possibility that the transformation process may not have progressed equally within the three realms.

Thus, the analysis of discourse, concept and practice allows us to see the entanglements between supply-driven and demand-driven processes and construct the notion of relevant trading spaces in which the different processes take place. In this respect, the proposed methodology is conducive to pointing out the preconditions of different continuities and ruptures, and it helps discern recurrences, interrelatedness, and common denominators on the one hand, and contradictions, paradoxes, and antagonisms on the other.

However, theoretical reflections can easily turn into an idealistic endeavour with strong ideas about how and why to proceed methodologically, but will the empirical sources reveal what you as a researcher hope for or will they only render connections and inspiration probable? We have drawn on official documents as well as archives at the Danish institutions where the education for peace experiments took place:

13 Cowen (2006), 566.

14 Noah, W. Sobe, "Entanglement and Transnationalism in the History of American Education," in Rethinking the History of Education: Transnational Perspectives on its Questions, Methods, and Knowledge, ed. Thomas S. Popkewitz (New York: Palgrave Macmillan, 2013), 93-107. 
Copenhagen City Archives, the Danish National Archive and the private archive of the former head of the National Centre for Pedagogical Experiments respectively. In order to be true to the transnational focus of the article, we have also consulted the archives of UNESCO and the Institute of Education London Archive containing the NEF archive. These archives have been studied with specific focus on international relations, connections, and idea development. The methodological strategy has been to track the movement of ideas and knowledge and follow their interpretations into the Danish sites of school experiments.

Armed with these methodological and empirical tools, the article addresses the following research question: How were international ideas, knowledge and practice of promoting peace through education transferred, translated, and transformed in Danish school experiments in interwar and post-war scenarios?

\section{Article structure and case studies}

We structure the article into one part treating the interwar period and one part treating the post-war period. The conclusion will weigh and discuss the findings in the two historical periods based on the methodological apparatus and the empirical reality.

To analyse the interwar period, we briefly describe the background of and clarify the initiatives of education for peace and their relations with the international progressive education movement. We then focus on the transnational space covering the NEF and the Danish school experiments launched at Frederiksberg and Vanløse (two municipalities neighbouring Copenhagen) in 1924.

The post-war period is treated with focus on the transnational space between UNESCO and the Emdrupborg Experimental School, founded in 1948; the Bernadotte School, instituted in 1949; and the National Centre for Pedagogical Experiments (Statens Poedagogiske Forsøgscenter), established in 1964. These institutions constitute solid examples of concrete transformation of ideas deriving from the transnational education space on Danish soil.

Although the ICIC of the League of Nations served as the obvious building block for UNESCO, we choose to focus on the NEF instead in our analysis of the interwar years. The NEF had very clear and explicit connections with the Danish progressive education movement, which was a key agent in the development of Danish educational policies and practices in that period. These connections are in evidence since the very formation of the NEF in 1921; in 1926 a Danish branch of the NEF, "The Free School" (Den frie skole), was formed, and in 1929 the connections were further cemented with the NEF international congress at Kronborg castle in Elsinore. ${ }^{15}$ We will elaborate on the links between progressive education and education for peace below. However, it should be duly noted that the League of Nations remained an important reference point and, as argued by Eckhardt Fuchs, succeeded in making education a public international affair, although it "[...] failed as an international center for various educational networks". ${ }^{16}$

15 Ydesen (2011).

16 Eckhardt Fuchs, "The Creation of New International Networks in Education: The League of Nations and Educational Organizations in the 1920s," Paedagogica Historica 43, no. 2 (2007), 209. 


\section{Education for peace}

The term "education for peace" refers to initiatives and activities at policy level as well as at a practice level. Thus, the concept includes politicians addressing ideas of basic education for all citizens, to raise educational levels and fight social inequalities to maintain stable and peaceful societies, and the development of specific social or academic competencies to support peace in the long term among pupils and students in educational institutions. ${ }^{17}$ These perspectives are intertwined in educational policy initiatives, pedagogic practices and experiments as shown in our analysis. The ideas of "education for all" and the comprehensive school demanded schools to develop and implement a new pedagogy, which embraced and included all children and social cultures and addressed social, cultural and international understanding directly in the content of subjects, for instance in textbooks. These ideas were introduced simultaneously in Danish public schools, and the close intertwinement stands out very clearly in our analysis.

Education for peace has been discussed since around $1800 .^{18}$ However, a regular and well-established peace movement did not emerge until the late 19th century. In the Nordic countries, peace societies were established during the 1880s, in Denmark in $1882 .{ }^{19}$ In 1890,1891 , and 1892 three world peace congresses were held in London, Rome, and Paris, respectively. Subjects such as breaking down the concept of "the enemy" and the promotion of international understanding were discussed. These tendencies had an impact on pedagogy and organisations advocating a new pedagogy aiming for peace in and between nations and preventing wars and international conflicts were founded. For example, the Scandinavian Teachers' Peace Association, founded in 1924, organised special courses on peace education for teachers every other year, ${ }^{20}$ and the ICIC took initiatives to revise textbooks to support peace through education. ${ }^{21}$ Their initiatives influenced educational policies and even led to a Ministry of Education circular ordering Danish schools to teach peace on the first Monday in September, the day the League of Nations Assembly met. In continuation of the opening quote, Minister Peter Munch wrote the following about this initiative:

It is not sufficient to do away with hatred. Even if this means a lot it is only the negative side of the task. We must also take up the positive side by teaching young people who are growing up now that common interest links all nations together. ${ }^{22}$

17 Mendhekar Dattatrya Parshuram, "Education for Peace," Indian Streams Research Journal 3, no. II (2013).

18 Gram-Skjoldager (2012).

19 S. Shepard Jones, The Scandinavian States and the League of Nations (London: Oxford University Press, 1939), 12.

20 Techniques on Education for International Understanding, Questionnaire, "Short report on the activities effected in schools and among youth organisations etc. in order to create better international understanding 1951," sent from the Danish United Nations Association, March 14, 1952, 327.6 A 55 ‘51', UNESCO Archive (UA).

21 Ellen Nørgaard, "Skolebogsbetænkningens historieafsnit: Dets tilblivelseshistorie og træk af dets modtagelse" [The Report on Textbook's Paragraph on History: Its Genealogy and Outlines of Its Reception], Årbog for dansk skolehistorie (1970), 89-106.

22 "Kronborg Magazine - Fifth International Conference on New Education," August 1929, Elsinore, Denmark, World Education Fellowship (WEF), III/186, Institute of Education London Archive (IELA), 27. Our translation. 
These observations attest to a focus on education for peace in the higher echelons of Danish society, i.e. among the Danish political elite, which is very much in alignment with the League of Nations. However, we turn our focus to the lower echelons of society, i.e. the bottom-up processes as manifested in schools and teacher networks as well as the links between progressive education and education for peace.

\section{The roots of progressive education and education for peace}

Different kinds of experimental schools were established during the 19th and early 20th centuries across Europe, founded or inspired by educational theorists such as Johann Friedrich Herbart (1776-1841), Friedrich Fröbel (1782-1852), and Maria Montessori (1870-1952), who all pointed to the importance of pedagogy and its role in child development and reflected on the ideas of progressive pedagogy. In England, Cecil Reddie (1858-1932) founded the Abbotsholme experimental school. In the United States, philosopher and psychologist John Dewey (1859-1852) was inspired by and further developed ideas of education for peace and its corresponding pedagogic practice. He pointed to the important role of socialisation and thus of pedagogy. ${ }^{23}$ Dewey also addressed the social perspectives of progressive education, for instance by pointing out that its aim is "to take part in correcting unfair privilege and unfair deprivation". ${ }^{24}$ Thoughts such as these became important cornerstones in the new pedagogy under development. Dewey had a position at University of Chicago and experimented with a new pedagogy in a so-called laboratory school, founded in 1896. This and other experimental schools became models for similar schools that experimented with new pedagogy during the 20th century. Among the more wellknown projects were the Dalton Plan, devised and implemented in 1917 by Helen Parkhurst (1887-1973); the Winnetka Plan, initiated 1919 by Carleton W. Washburne (1889-1968), and the Decroly School, established in Belgium by Ovide Decroly (1871-1932). Dewey described the ideas of the new education in progressive schools as opposed to existing pedagogy, defined by emphasising "expression and cultivation of individuality", free activity, learning through experience, the acquisition of skills "as means of attaining ends which make direct vital appeal", "preparation for making the most of the opportunities of present life", and "acquaintance with a changing world". 25

As argued, the underlying variable behind the international progressive education movement was education for peace. At the progressive education meeting in Helsinki, Finland, in August 1938, the chair of the Finnish NEF section, headmaster Laurin Ziliacus (1895-1959), gave a closing lecture in which he characterised the international progressive education movement. One of the central traits emphasised was: "a strong and determined internationalism" in which child rearing was seen as "the best way of building a happier world; a world without war". ${ }^{26}$ With this link between progressive education and education for peace established, it is time to focus on the interwar years and the NEF, the key international progressive education organisation of that period.

23 John Dewey, "My Pedagogic Creed," School Journal 54, no. 3 (1897), 77-80.

24 John Dewey, Democracy and Education: An Introduction to the Philosophy of Education (New York: Courier Dover Publications, 2004 [1916]), 115.

25 John Dewey, Experience \& Education (New York: Simon and Schuster, 2007 [1938]), $19 f f$.

26 Laurin Ziliacus, "Den nye opdragelse af idag" [The New Rearing of Today], Den Frie Skole 12, no. 1 (1939), 3-8. 


\section{The interwar years The NEF}

The NEF was founded in 1921 with a strong belief in a new international education for international understanding. ${ }^{27}$ Since its formation at a conference in Calais, France, the NEF's reputation and prominence on the international pedagogical scene "as an international body facilitating the exchange of educational ideas and practices" snowballed. $^{28}$

The NEF was a motley and complex group consisting of lay enthusiasts and major figures on the international educational scene, including Maria Montessori, Adolphe Ferrière (1879-1960), Ovide Decroly, Carl Gustav Jung (1987-1961), Jean Piaget (1896-1980), and John Dewey. ${ }^{29}$ The numerous points of view were not all compatible, rooted as they were in theosophy and spiritual elements, as well as psychology and positivistic science. However, the lodestar of the organisation was the individual potential of the human being and education for peace. ${ }^{30}$ The key terms here are international understanding, world consciousness, and world citizenship. ${ }^{31}$

The international links between the Danish progressive education movement and the NEF can be described as a trading space: "The New Education Fellowship provided a learning community in which educators sought to define their role in the 'new' within the wider context of an international community of practice." ${ }^{2}$ But the $\mathrm{NEF}$ also functioned as an organisation that could generate authority in educational debates on national scenes.

\section{Linking the NEF and the Danish progressive education movement}

In the early 20th century, the Danish progressive education environment consisted of several factions, which can generally be categorised into two groups: the folk high school movement inspired by N. F. S. Grundtvig (1783-1872) and Christen Kold (1816-1870), and the progressive education movement. ${ }^{33}$ Both groups made noteworthy contributions to education for peace in Denmark. The folk high school movement framed the International People's College, established by Peter Man-

27 Beatrice Haenggeli-Jenni, “Le rôle des femmes de la Ligue Internationale pour l'Education Nouvelle dans la circulation des savoirs pédagogiques (1920-1940)," in Les savoirs dans le champ éducatif: circulations, transformations, implémentations - Pour une histoire sociale de la fabrique internationale des savoirs en éducation 19e-20e siècles, ed. Joelle Droux and Rita Hofstetter (forthcoming); Kevin Brehony, "A New Education for a New Era: The Contribution of the Conferences of the New Education Fellowship to the Disciplinary Field of Education, 1921-1938," Paedagogica Historica 40, nos. 5-6 (2004), 733-55.

28 Ibid., 745 .

29 Ibid., 734.

30 William Boyd and Muriel M. MacKenzie, eds., Towards a New Education: A Record and Synthesis of the Discussions on the New Psychology and Curriculum at the Fifth World Conference of the New Education Fellowship at Elsinore, Denmark, in August 1929 (London: A.A. Knopf, 1930); Beatrice Ensor, "Outlook Tower," The New Era 10, no. 37 (1929): 3-8; Laurits Suhr, "Arbejdsskolen” [The Work School], Vor Ungdom [Our Youth] (1923), 158-65.

31 Brehony (2004), 740; Ensor (1929), 7.

32 Margaret White, “The New Education Fellowship: An International Community of Practice," New Era in Education 82, no. 3 (2001), 71-75.

33 J. Nielsen, "Denmark," Educational Yearbook of the International Institute of Teachers College (New York, 1936), 250-68; Nørgaard (1977), 45f.; Sofie Rifbjerg, Trok af den moderne opdragelseshistorie (Copenhagen: Gyldendal, 1966); S. Simonsen, "A Dalton Plan Experiment in Denmark," The New Era 10, no. 37 (1929), 60. 
niche (1889-1981) in Elsinore in 1921 to "bridge the gulf of estrangement that exists among the nations of the world by receiving students from different countries." 34

The progressive education movement drew inspiration from international pedagogical currents ${ }^{35}$ and continuously sought to influence the Danish educational field via journals, pedagogy in courses, presentations at conferences, and school experiments. ${ }^{36}$

The connection between the Danish educational field and the NEF was formally institutionalised in May 1926 with the formation of Den Frie Skole (The Free School) as an official section of the NEF. The work programme of the Danish NEF section said: "We want the school to promote international understanding, because - more than ever - we are convinced that nations must settle their disputes peacefully." ${ }^{37}$ Thus, the Danish progressive education movement and the NEF keenly tried to promote a spirit of cooperation rather than competition among children. This implied the abolition of the existing examination system, which was seen as promoting competition and replicating social inequalities, stifling and hampering the potential of the individual child. Georg Julius Arvin (1880-1962), chairperson of the Danish NEF section, wrote in his description of the Danish education system to the NEF:

In the present examination system, we have the greatest hindrance to freedom in the school. It is therefore, quite natural that the New Education Fellowship has submitted this question to serious consideration and formed a committee aiming to work out suggestions for a new examination system. In this country, where Grundtvig has spoken so sharply against the lesson school which began "with letters and ended with books", one would expect the people to take a special interest in the struggle against examinations; nevertheless we have a pronounced examination system. ${ }^{38}$

In August 1929, the NEF held its all-time biggest conference at Kronborg Castle in Elsinore, with around 2,000 participants from 43 nations. ${ }^{39}$ The conference was

34 “Kronborg Magazine - The Fifth International Conference in New Education," August 1929, WEF III/186, IELA, 47.

35 Many Danish teachers travelled to England, Germany, Sweden, Norway, and the United States in the 1920s to learn about educational trends and experiments abroad. Between 1918 and 1959, 34 Danish teachers studied at Teachers College, Columbia University (student records, Teachers College, Columbia University). Of these, 21 went to Teachers College between 1923 and 1938 (Report on the International Institute of Teachers College to the Rockefeller Foundation, 1939, Table I, 94). Between 1915 and 1927, the distribution of Danish teachers travelling abroad with a Ministry of Education grant was: England 60, Germany 40, Sweden 40, Norway 20, France 32, Italy five, and Holland three. This is obviously not an accurate picture, since many teachers travelled without grants from the ministry, but it still says something about the regions and schools to which Danish teachers looked for inspiration. "Rejseindberetninger fra lærere med understøttelse til studierejser i udlandet" [Travel Accounts from Teachers with a Grant for Study Trips Abroad], 1917-1927, Ministry of Education, Danish National Archives (DN).

36 Our study of the journal of the Danish NEF section, Den Frie Skole, in the 1920s and 1930s testifies to a profound international outlook: It carries numerous articles from, inter alia, the rest of Scandinavia, England, Scotland, the United States, Germany, Italy, and Belgium.

37 "Den Frie Skoles Arbejdsprogram" [Work program of the Free School], Den Frie Skole 12, no. 3 (1938), 1.

38 “Kronborg Magazine - The Fifth International Conference in New Education," August 1929, WEF III/186, IELA, 29f.

39 Eckhardt Fuchs, "Educational Sciences, Morality and Politics: International Educational Congresses in the Early Twentieth Century," Paedagogica Historica 40, no. 5 (2004), 757-84. 
of utmost importance in the international educational field, and according to the conference report book, "it is no exaggeration to say that this book contains the truest account available anywhere of the various currents of progressive educational thought in the world at this critical time." 40

The conference convened under the auspices of the Scandinavian ministers of education, and the Danish Prime Minister Thorvald Stauning (1873-1942) gave the opening address. The organising committee consisted of members from the Scandinavian countries; among them leading members of the Danish progressive education movement, the prominent Swedish educator Nils Hänninger (1887-1968), and the Norwegian headmistress and chairperson of the Norwegian NEF section, Anna Sethne (1872-1961).

Because of its magnitude, the conference had a significant impact in Denmark and, from a theoretical perspective, is an exceptional example of a transnational trading space where ideas and even practices could travel. ${ }^{41}$

In this context, a noteworthy feature of the NEF conference was a study group entitled "Education for International Understanding". The group presented a programme of papers by participants from several different countries, many of which addressed peace, international understanding, and cooperation. The Anglo-American participants presented: ${ }^{42}$ "Creating the International Mind in Youth through Education" by J. E. H. Fanshawe, Director General, Brooks-Bright Foundation; "International Understanding through Language" by J. J. Findlay, Honorary Professor of Education, University of Manchester, England; and "Racial Prejudice in Children of School Age" by G. H. Green, Lecturer at the Department of Education, Aberystwyth, Wales, and S. Herbert Lecturer at the University College of Wales, Aberystwyth, Wales.

This working group and its international contents testify to the central position of international understanding and education for peace within the progressive education movement. Moreover, it would have served as a source of inspiration for many of the participating and interested Danish teachers and educationalists, creating the opportunity for the transfer, translation, and transformation of ideas, knowledge and practice about education for peace.

With this link between international progressive education space and the Danish progressive education movement established, it is time to focus on the practices of education for peace in the school experiments at Frederiksberg and Vanløse.

\section{School experiments at Frederiksberg and Vanløse}

In the 1920s and 1930s, the Frederiksberg educational system was a progressive hub for educational experiments and new educational practices. As early as 1924, the first official experimental class was established at Howitsvejens skole. A couple of unofficial experimental classes at Lollandsvejens skole were closed in 1928, only to be resurrected in 1930 at La Cours Vejens skole. ${ }^{43}$

40 Michael Sadler, "Introduction," in Towards a New Education: A Record and Synthesis of the Discussions on the New Psychology and Curriculum at the Fifth World Conference of the New Education Fellowship at Elsinore, Denmark, in August 1929, ed. William Boyd and Muriel M. MacKenzie (London: A.A. Knopf, 1930), xi.

41 Ydesen (2011).

42 Programme for the Elsinore conference, WEF III/186/1929, IELA.

43 Olaf de Hemmer Egeberg, "Forsøgsarbejdets kaar i Danmark" [The conditions of experimental work in Denmark], Den Frie Skole 4, no. 9 (1931), 139-41. 
In 1918, the aforementioned Arvin was appointed headmaster of the Skolen $p a$ la Cours Vej (The School at la Cours Vej), a position he held until 1939. As an educator, Arvin saw himself as inheriting the work of German reform educator Georg Kerschensteiner (1854-1932) and his concept of Arbeitsschule (work school). ${ }^{44}$ The Skolen på la Cours Vej was thus an interesting trading space for transfers and translations of international educational ideas and practices, not least because Arvin was given the freedom by the school directorate to realise many of his reformist ideas. ${ }^{45}$ One example was the establishment of the very first Montessori kindergarten as an attachment to the school in 1920.

Arvin made tremendous efforts to establish contact with the international pedagogical field, making several visits abroad. Furthermore, a steady stream of international visitors came to see the Skolen på la Cours Vej, including from Japan, Thailand, and the United States. ${ }^{46}$ Arvin also made the school a place where Danish progressive educationalists could find like-minded people; i.e. a sanctuary from the lifted eyebrows of the educational establishment and its grudge against the progressive education movement. One example is the well-known progressive educationalist Torben Gregersen (1911-1994) and secretary of the Danish NEF section, who worked as a teacher at the Skolen på la Cours Vej between 1935 and 1943. Many others were invited to give talks for teachers and parents, numbering among their ranks the educational psychologist Sofie Rifbjerg (1886-1981), who had studied the works of Maria Montessori, Cyril Burt, the leading educational psychologist at the time, and Olaf de Hemmer Egeberg (1887-1959), a teacher in the Vanløse experimental classes. In his description of the Vanløse classes, Egeberg emphasised the following:

In our age, human beings of a different mould are needed, human beings with cleaner and higher ideals. We need brave and energetic human beings who can make sound judgements and have the will and ability to enter into the right relation with other human beings so that the building and entire structure of societies may be shaped according to better and more just lines than has so far been the case. ${ }^{47}$

Gertrud Lundholm (1890-1981) describes her work in the Vanløse experimental classes to the NEF as follows:

Now [the pupils] demanded to know the real history of Denmark, and we brought forward the times of the Vikings, not from the standpoint of Denmark's time of power, but from the causes to the great movement in Europe, and from the thought that man, of course, could not then think as we. ${ }^{48}$

Another teacher's diary from the Vanløse experimental classes reflects the ideas of the new progressive pedagogy put into practice. Very similar to the Frederiksberg practices, the pedagogy adapted challenges to pupil development and competencies

44 “Kronborg Magazine - The Fifth International Conference in New Education," August 1929, WEF III/186, IELA, 30.

45 Georg Julius Arvin, Tryksager, Avisudklip [press clippings], 1856-1956, DN.

46 Helge Jensen, “Arvin og skolen på La Coursvej," Poedagogisk-psykologisk tidsskrift (1950), 139-46.

47 Speech by Egeberg in August 1927, reproduced in Spæt Henriksen and Ellen Nørgaard, Vanløsedagbogen: En reformpoedagogisk praksis [The Vanløse Diary: A reform pedagogical practice] (Copenhagen: Gyldendals pædagogiske bibliotek, 1983). Our translation.

48 "Kronborg Magazine - The Fifth International Conference in New Education," August 1929, WEF III/186, IELA, 34f. 
and gave pupils freedom to choose the activities in which they wanted to engage, prevented competition and supported cooperation and social understanding. ${ }^{49}$

Thus, the Skolen på la Cours Vej and Vanløse classes can be characterised as important beachheads for progressive education in general and for education for peace in particular in Denmark.

However, the educational climate in Denmark in the interwar years was highly antagonistic. ${ }^{50}$ The 10 Vanløse experimental classes were suddenly and without warning terminated in 1928 by the Copenhagen School Directorate a few days before the evaluative test agreed on in 1924 was scheduled to take place..$^{51}$ The decision was made by the conservative Mayor of Education Ernst Kaper (1874-1940), who wanted an "efficient and uniform" school system in Copenhagen, one in which children could be easily moved from one school to another. ${ }^{52} \mathrm{He}$ had endorsed the experiment in 1924 because he saw it as a valve that would relieve some of the pressure in the educational system generated by the progressive education movement and its criticism of the existing educational system. ${ }^{53}$ However, with widespread attention and parental support to the experimental classes, what had started as a stream was turning into a dangerous current. Another constrainer of possibilities, the Social Democratic member of the Copenhagen City Council also supported the decision, fearing that acquisition of useful subject knowledge had suffered in the experimental classes. ${ }^{54}$ The whole affair testifies to the intense struggles in Danish education in the interwar years and shows that the progressive education movement and its ideas were often unwelcome among both conservative and Social Democratic politicians.

Using the Frederiksberg and Vanløse school experiments as analytical objects on the backdrop of the trading space between the international progressive education movement, epitomized by the NEF, and the Danish progressive education movement has revealed a high level of transfer and translation of education for peace ideas. The quotes are very much in alignment with international ideas about education for peace. For instance, when Gregersen talks about "a new mould of human beings" it is in alignment with the international discourse found in the ranks of the NEF. At the same time, it has become clear that the Danish progressive education movement was in opposition to the educational establishment. Fierce criticism from influential agents like Ernst Kaper further unified progressive educationalists and they drew on the international space of like-mindedness to find rejuvenation and new arguments for their struggle. In terms of transformation it meant that significant social and economic power was imposed on the translated practices. But, gradually, some progressive educationalists like Arvin became more influential and provided sanctuaries for the idea of progressive education. However, it is important to note that education for peace was but one component - although an overarching one - in the educational struggles of the interwar years. Other battle scenes were the evaluation system, the question of differentiation, the level of standardization in the organisation, and the didactical guidelines of the education system.

\footnotetext{
49 Henriksen and Nørgaard (1983).

50 Ydesen (2011).

51 Nørgaard (1977), 88.

52 Henriksen and Nørgaard (1983), 14.

53 Ibid., 25.

54 Ibid., 30.
} 


\section{The post-war years \\ The NEF and UNESCO}

There were some clear lines of continuation between the interwar and post-war periods concerning education for peace. First and foremost, the NEF international office in London was closely associated with the newly established UNESCO and even received a subvention from UNESCO to promote the work of international understanding through surveys and projects. ${ }^{55}$

According to Gregersen, the NEF had consultative status in UNESCO and was one of six organisations invited to contribute a memorandum to UNESCO's enquiry into Tensions Affecting International Understanding. Furthermore, the NEF published for UNESCO a special issue of The New Era devoted to "Children's Communities" and Professor Henri Wallon, president of the NEF section in France, was chairperson of the Education Committee of UNESCO's National Commission for France, while Dr Rupert Best, of the executive board, represented the NEF on UNESCO's National Commission for Australia. ${ }^{56}$

In November 1949, Gregersen presented at Emdrupborg his impressions from the NEF summer conference held in August 1949 in the English town of Cirencester. The theme of the conference was the development of attitudes favourable to international understanding. ${ }^{57}$ Among other things, Gregersen emphasised UNESCO's project Tensions Affecting International Understanding. The project was headed by Professor Klineberg from Columbia University, and it involved sociologists from 16 nations, focused on textbook improvement, empirical investigations into stereotypes, and experiments on how attitudes can be changed.

UNESCO came into existence in 1946 and, as a newly emerging international player, played its role in decolonisation and post-war reconstruction by initiating and promoting major international projects aimed at improvements in general education, school teaching, and mutual understanding among nations. One of the first goals proclaimed by UNESCO was to cultivate "unity in diversity" to achieve a better cross-cultural relationship and cooperation between diverse human communities. The important agenda that UNESCO set within this goal was to find "new ways of living peacefully together". Among its key initiatives in this regard were education for international understanding and improvement of textbooks as an aid to international understanding. In 1947, UNESCO held a major seminar in Sèvres, France, on education for international understanding, with several Danish representatives. ${ }^{58}$ The working group on Social Studies Teaching and International Understanding drew conclusions and guidelines on how to implement national programmes for

55 Letter from Torben Gregersen to Miss Clare Soper, 13 May, 1950, WEF II/80-81, IELA; Joseph Watras, "The New Education Fellowship and UNESCO's Programme of Fundamental Education," Paedagogica Historica 47, no. 1-2 (2011), 191-205.

56 New Education Fellowship pamphlet, Torben Gregersen, 1940-1993, "Diverse sager" [Miscellaneous], DN. The pamphlet is undated but probably from 1949, since it mentions a "forthcoming conference" to be held in Cirencester in August 1949.

57 New Education Fellowship, “Can we do something for peace and freedom through rearing?," talk held at Emdrupborg Experimental School, 16 November, 1949, Torben Gregersen, 1940-1993, "Diverse sager" [Miscellaneous], DN.

58 “Education for International Understanding," Sèvres, 1947, 327.6-37 A 074 (44) ‘47', UA. 
international understanding in schools, for instance by producing better informational materials for teaching, such as pamphlets and textbooks. ${ }^{59}$

Further, the UNESCO programme resolution formulated in 1950 (no. 2.513) addressed the role of schools and school experiments:

The Director-General is instructed to take steps towards the drafting of a convention under which the Member States may agree, with the limits of their legal powers, to ensure their educational programmes are directed at all levels towards international peace and security. ${ }^{60}$

Denmark, among other countries, set up a committee to supervise and coordinate the experimental activities in schools associated with the UNESCO programme in International Understanding and Co-operation at the national level. ${ }^{61}$ Several experiments were implemented, and the Emdrupborg Experimental School's experiments were among the most prominent and influential.

\section{The Emdrupborg Experimental School and the Bernadotte School}

On November 26, 1947, the Copenhagen School Directorate decided to establish an experimental school in the Emdrup neighbourhood, northwest of central Copenhagen. ${ }^{62}$ The school was inaugurated on August 13, 1948, under the leadership of former Vanløse teacher, NEF member, and now educational psychologist Anne Marie Nørvig (1893-1959). ${ }^{63}$

The pedagogical ideas and practices at Emdrupborg found inspiration in the international progressive education movement in general, as well as Abbotsholme and Dewey's Laboratory School in particular testifying to a transfer, translation and transformation process. ${ }^{64}$ An example from Danish language lessons, described in a report by Jørgen Egedal Poulsen (b. 1921), a teacher at the school, illustrates the ideas of such practice. Poulsen describes pedagogy as having:

$[\ldots]$ its greatest value in the rearing for cooperation and thus a democratic attitude. The pupils are taught to listen to other people's opinions, learn something about themselves in the social interaction, and get an opportunity to advance opinions and ideas, giving everybody the possibility to contribute to the common cause. ${ }^{65}$

59 "Education for International Understanding," Sèvres, 1947, part IV, reports, foreword, working papers etc., "Social Studies Teaching and International Understanding," 27 August, 1947, 327.6-37 A 074 (44) '47', UA, $42 \mathrm{f}$.

60 See http://unesdoc.unesco.org/images/0016/001617/161776eb.pdf and http://unesdoc.unesco.org/ images/0014/001443/144371eb.pdf.

61 "Seminar on Education for Living in a World Community - Netherlands 1952 follow up," newsletter to former seminar participants, 30 January, 1955, 327.6 A 074 (492), UA, 4.

62 "Beretning om Københavns Skolevæsen" [Account about the Copenhagen Educational System], 1947-1948, Copenhagen City Archives (CA), 8.

63 Anne Marie Nørvig, "Vor skoles struktur er ikke tidssvarende" [Our School Structure Is Not Up-toDate], Land og folk, 14 August, 1948, $5 \mathrm{ff}$.

64 Jørgen Egedal Poulsen, "Kontinuitet i forsøgsarbejdet i sidste halvdel af det 20. århundrede - Den selvudviklende skole" [Continuity in the Experimental Work in the Latter Half of the 20th Century - The Self-Developing School] (1998), Statens Pædagogiske Forsøgscenter (SPF), DN, Chapter 4.

65 Jørgen Egedal Poulsen, "Danskundervisning på Emdrupborg Skole" [Teaching in Danish at Emdrupborg School] (1963), SPF, DN. Our translation. 
The quote clearly relates to the shared concepts and discourse of UNESCO and the Council of Europe with their emphasis on cooperation and democratic attitude, but it also relates to the Danish public post-war debates about democracy. ${ }^{66}$ Theologian Hal Koch (1904-1963) had argued that democracy is a lifestyle and not something reserved for the higher echelons of the political system. In this light the quote also indicates a transformation of international ideas about democracy in education.

Another example is the visit by a delegation from the Council for Education in World Citizenship, headed by Margaret Quass, to Emdrupborg in August 1954. ${ }^{67}$ The council was founded in 1939 as an independent organisation dedicated to education for international understanding, for young people of all ages. The organisation had very close and cordial ties with UNESCO. ${ }^{68}$

Moreover, the majority of the experimental school staff, including Nørvig and the three other educational psychologists employed, were members of the Danish NEF section. ${ }^{69}$ After its establishment, the Danish NEF section found Emdrupborg a suitable place for presentations, talks, and other events. One speaker was Alexander Sutherland Neill (1883-1973), founder and headmaster of the Summerhill progressive school. In August 1953, the NEF held a significant two-week international conference at Askov High School with 270 participants, and many foreign NEF section representatives visited Emdrupborg, as well as several prominent international NEF members, including Laurin Zilliacus (October 1953), Ruth Frøyland Nielsen (July 1953), and Professor Joseph Albert Lauwerys (1902-1981), deputy chairperson of the NEF and a frequent expert in UNESCO work (March 1950 and summer 1959). Speaking about the Emdrupborg complex of educational institutions at the Royal Danish School of Education on June 16, 1948, Arvin said, "As chairman of the Danish NEF section, I dare add my wish that Emdrupborg may be a link between Nordic and international pedagogy." ${ }^{20}$

Another important post-war institution was the autonomous Bernadotteskolen also known as the International School - founded by Arvin in August 1949 and run according to UNESCO's educational ideas. ${ }^{71}$ Bernadotte worked as a comprehensive school, which was ground-breaking at the time. A staunch supporter of the school was Minister of Education Hartvig Frisch (1893-1950), who, in a teacher's union speech, said, "If we enter into a peaceful era, Denmark will enjoy a prosperous pedagogical age" and "it is natural if Denmark enters cultural collaboration with UNESCO right from the start." ${ }^{\prime 2}$

66 Thomas Nygren, "UNESCO and Council of Europe Guidelines, and History Education in Sweden, c. 1960-2002," Education Inquiry 2, no. 1, (2011), 37-60.

67 Emdrupborg school archive, guestbook 1948-1965, CA.

68 Derek Heater, Peace Through Education: The Contribution of the Council for Education in World Citizenship (London: Falmer Press, 1984).

69 Forms submitted from Sofie Rifbjerg to Miss Clare Soper, Membership Secretary of the NEF, dated February 1, 1933, WEF II/80, IELA; Niels Rosendal Jensen, "Kampen for enhedsskolen - forsøget på Emdrupborg," Arbejderhistorie 2 (1998), 45-59.

70 Georg Julius Arvin, Tryksager, Avisudklip [Press Clippings], 1856-1956, DN.

71 Pamphlet entitled “The International School, Denmark,” WEF II/81, IELA.

72 "Allerede i børnehaven lærer de små engelsk - Rektor Arvin om den internationale Bernadotteskole i Hellerup" [The little ones learn English already in pre-school - Headmaster Arvin about the international Bernadotte school in Hellerup], Aftenbladet København, 15 August 1949; "Får enhedsskolen nu sin chance" [Will the comprehensive school get its chance], Aftenbladet København, 26 November, 1948. 
Arvin's initiative immediately enjoyed wide national and international support. Mads R. Hartling (1885-1960), minister of education November 7, 1945-November 13, 1947, and the Danish UNESCO representative supported the formation of a committee in 1947 with the purpose of establishing the Bernadotte school, a committee whose supporters also counted the British and American ambassadors. ${ }^{73}$

These observations testify to the presence of strong international routes from the international space of peace education where Emdrupborg and the Bernadotte School served as hubs of progressive educational ideas as expressed by the NEF and UNESCO. In line with our theoretical framework the movements can be expressed as translations of transnational ideas while the subsequent practices of the institutions constitute transformation processes.

\section{The National Centre for Pedagogical Experiments}

In 1963, the Danish Minister of Education Kristen Helveg Petersen (1909-1997) initiated the preparatory work for a Danish National Centre for Pedagogical Experiments. The overall purpose of the centre was to conduct experiments on how to implement the ideas expressed in the recent Education Act of 1958. The executive order following the act in 1960 - called the Blue Report because of its blue cover - emphasised a pedagogy that reflected the ideas of the progressive education movement and the agreements of the UNESCO constitution. In this respect the education act of 1958 and the ensuing Blue Report - i.e. the ideas expressed in these documents are evidence of transformation resulting in changes in the Danish education system. About the pedagogy of the Folkeskole, the Blue Report states that "promoting children's sense of international understanding and cooperation among the peoples must be prioritized." ${ }^{74}$ Concerning the purpose and visions for a centre for pedagogical experiments, the report states that it should "give young people the opportunity to familiarise themselves with the conditions under which the democratic institutions work." 75 The concept of lifelong education introduced and developed by UNESCO during the 1960s also became influential for the activities of the centre. ${ }^{76}$

After years of preparation, the Danish National Centre for Pedagogical Experiments was established in May 1964. Poulsen was the leader of the working group, which formed the basic principles for the school, and was appointed the first head of the school. Poulsen had worked at the Emdrupborg Experimental School from 1949 until 1963 as a psychologist and a teacher in the experimental classes, and the general ideas for the purpose and pedagogy of the National Centre were highly inspired by the practice of Emdrupborg ${ }^{77}$ and by the Bernadotte school.

73 Pamphlet entitled “The International School, Denmark," WEF II/81, IELA; Georg Julius Arvin, Presseklip [press clippings], 1856-1956, DN.

74 Undervisningsministeriet (1960), "Undervisningsvejledning for Folkeskolen," Betænkning no. 253, 6.

75 Jørgen Egedal Poulsen, “Ungdomsbyen, 1958-1963” [The Youth City, 1958-1963] (1994), SPF, DN, 11.

76 UNESCO (1966), International Committee for the Advancement of Adult Education, Unesco House, December 9-17, 1965, Report of the third session, Paris 1966; K. Andersen et al., "Det innovative arbejde 1975-76" [The Innovative work 1975-76], Årbog [Yearbook] (Copenhagen: Statens Pædagogiske Forsøgscenter, 1976).

77 Jørgen Egedal Poulsen, "Forsøgscentrets første år" [The first years of the experimental centre], in Beskrivelse og indføring i lokalarkivet [Description and introduction to the local archive] (Copenhagen: Statens Pædagogiske Forsøgscenter, 1993). 
The committee's recommendation to the Ministry of Education describes the centre's pedagogical ideas:

\begin{abstract}
It should be emphasized that the task of the centre is to not only gather experiences about educational practices, but also to test a number of the pedagogical views expressed in "The Blue Report", including interdisciplinary collaboration and free forms of teaching. [...] The centre must pay close attention to the preparation of youth for the responsibilities of a democratic society and the centre must support all possibilities to appeal to the pupils' commitment to this important area. ${ }^{78}$
\end{abstract}

International understanding and international cooperation were focal points in the pedagogy emphasising the trends, recommendations and conventions from international organisations such as the Council of Europe, OECD, CERI and IMTEC. ${ }^{79}$ Reports reveal extended international cooperation, for instance participation in international conferences, study tours to experimental schools, or innovative educational projects. In addition, the centre was a very active participant in conferences held by CERI. ${ }^{80}$

The centre had an obligation to disseminate experiences from experiments and thus had an extensive production of publications and reports and established cooperation with schools and teachers all over the country. Such activities spread the ideas of a modernized pedagogy as outlined above, bringing it into practice at schools and translated into specific school contexts. Over time, education legislation, especially the Education Act of 1975, adopted several ideas from the pedagogy of the centre's school experiments.

\title{
Conclusion
}

Based on the research question "how were international ideas of promoting peace through education transferred, translated, and transformed in Danish school experiments in interwar and post-war scenarios?", the article demonstrates a strong and recurring international outlook in the Danish educational field in the two periods treated, testifying to the existence of strong links and routes to the international education space. The article has used a transnational approach and examined the travel routes for ideas, knowledge and practices concerning education for peace from the trading spaces associated with the progressive international education movement into the most significant school experiments. The ideas exchanged in these forums had significant influence on Danish educational policy and pedagogic practice. Our analysis has shown that an unequivocal transnational dimension was present in $\mathrm{Da}-$ nish school experiments pertaining to education for peace. Via this transnational dimension, Danish agents participated in fora where ideas, knowledge, and descriptions of practices were exchanged. When we were unable to follow the transfer, tran-

78 Cited from a letter to Hr. kontorchef, Cand.jur E. Tøttrup, Dansk Arbejdsgiverforening, Vester Voldgade 113, 10 June, 1963, v. Private Archive of Jørgen Egedal Poulsen, Our translation.

79 Ibid., 2, Jørgen Egedal Poulsen, “International forskning, skoleforsøg og erfaringer inddrages i dansk forsøgsvirksomhed" [International research, school experiments and experiences are integrated in Danish experimental activities] (1998), SPF, DN, chapter 9.

80 Jan Bengtsson, "Centre for Educational Research and Innovation (2008), OECD's Centre for Educational Research and Innovation-1968 to 2008," OECD, http://www.oecd.org/site/educeri21st/40601796.pdf. 
slation and transformation practices minutely, we have argued for the probability of such travels and domestication of the transnational.

Education for peace has been defined and understood as intertwined ideas of offering basic education to all citizens, raising the educational level in nations, and fighting social inequalities to maintain stable and peaceful societies, and supporting the development of specific competencies among pupils and students to support peace in society in the long term.

The historical analysis identified significant trading spaces for the transfer, translation, and transformation of education for peace. In the interwar years, the NEF with its Danish section in general and the NEF conference in Elsinore in particular, the Skolen på la Cours Vej and the Vanløse experimental classes proved to be such significant spaces. They also indicate, however, that the practices containing education for peace ideas were met with opposition which influenced the way such practices could be transformed in a Danish context. In other words, education for peace initiatives had to merge and confluence with existing practices demanding significant adjustments.

In the post-war period, the NEF still played an important role, but was joined by UNESCO and among others the Council of Europe at the international level. In the Danish educational field, the Emdrupborg Experimental School, the Bernadotte School, and the National Centre for Pedagogical Experiments proved to be important sites for the translation and transformation of ideas on education for peace.

It is, however, important to note a difference between the two periods. During the interwar years the local educational contexts were mostly influenced by grassroots, bottom-up processes, and even personal contacts - although there were some references to the League of Nations. The post-war period was characterised by more institutionalised international collaboration - both internationally in relation to UNESCO and in the Danish educational field as such - with more formal institutions being founded.

When we assess the impact of ideas, knowledge and practices of international education for peace, it is noteworthy that the interwar years demonstrate a rather close transfer of ideas, knowledge and practices being translated into concrete educational initiatives at Frederiksberg and Vanløse. Undoubtedly, this "unpolluted" travel route was paved by close personal relations with foreign peers, via, for example, the NEF and a strong sense of opposition to the existing educational system which was shared by many progressive educators of the interwar years. These conditions account for the strong cross-border fellowship of like-mindedness. As a consequence of the complex nature of these processes and the qualitative character of the influences in focus, it is of course not possible to "measure" the "magnitude" of these impacts and influences. This basic condition is reflected in our analytical approach which makes it possible for us to focus on the processes in order to find the traces pointing to the influences where they did unfold, and how the processes seems to have been initiated. Our documentation include the international communities to which educators themselves refer when they describe their primary inspirations and the fora in which they shared and developed ideas and made agreements, to be implemented in the local contexts.

In keeping with the gradual institutionalisation of the post-war years, the ideas on education for peace were mixed to a higher degree with national policies, testify- 
ing to stronger translation and transformation processes compared to the interwar years, where at least the travel routes of transfer seem to have been less "polluted". The transformation processes of the post-war years are in evidence in the institutions created, the practices they instituted and in legislations and political initiatives as described in the examples. At the same time, the antagonisms in the Danish educational field of the interwar years were strongly reduced, probably because the German occupation had sparked a sense of reconciliation, community, and national fellowship around the values of democracy in education, making it meaningful to interpret the post-war differences in the Danish educational field as differences of degree rather than differences of nature. 


\section{References}

\section{Archival sources}

UNESCO archive (UA)

327.6 A 55 '51', Techniques on Education for International Understanding, Questionnaire, "Short report on the activities effected in schools and among youth organisations etc. in order to create better international understanding 1951," sent from the Danish United Nations Association, March 14, 1952.

327.6-37 A 074 (44) '47', Education for International Understanding, Sèvres, 1947, part IV, reports, foreword, working papers etc., "Social Studies Teaching and International Understanding," August 27, 1947, http://unesdoc.unesco.org/images/0016/001617/161776eb.pdf; http://unesdoc.unesco.org/images/0014/001 443/144371eb.pdf.

327.6 A 074 (492), Seminar on Education for Living in a World Community - Netherlands 1952 follow up, newsletter to former seminar participants, January 30 (1955).

UNESCO (1966), International Committee for the Advancement of Adult Education, Unesco House, December 9-17, 1965, Report of the third session, Paris 1966.

\section{Institute of Education London Archives (IELA)}

World Education Fellowship (WEF)

II/80, forms submitted from Sofie Rifbjerg to Miss Clare Soper, Membership Secretary of the NEF, dated 1st February 1933.

II/80-81, Letter from Torben Gregersen to Miss Clare Soper, 13 May, 1950.

II/81, pamphlet titled "The International School, Denmark."

III/186, "Kronborg Magazine - Fifth International Conference on New Education," August 1929, Elsinore, Denmark.

III/186, Conference programme.

Danish National Archives (DN)

Ministry of Education, Rejseindberetninger fra lærere med understøttelse til studierejser i udlandet, 1917-1927.

Georg Julius Arvin, Tryksager, Avisudklip, 1856-1956; Presseklip, 1856-1956.

Statens Pædagogiske Forsøgscenter (SPF)

Jørgen Egedal Poulsen. "Kontinuitet i forsøgsarbejdet i sidste halvdel af det 20. århundrede - Den selvudviklende skole." (1998).

Jørgen Egedal Poulsen, "Danskundervisning på Emdrupborg Skole.” (1963).

Jørgen Egedal Poulsen. "Ungdomsbyen, 1958-1963." (1994).

Jørgen Egedal Poulsen. "International forskning, skoleforsøg og erfaringer inddrages i dansk for-søgsvirksomhed." (1998).

Torben Gregersen, 1940-1993, Diverse sager.

Copenhagen City Archives (CA)

Beretning om Københavns Skolevæsen, 1947-1948.

Emdrupborg school archive, guestbook 1948-1965.

Private archive of Jørgen Egedal Poulsen

Private Archive. Letters. 


\section{Literature}

Andersen, K. et al., "Det innovative arbejde 1975-76.” Årbog. Copenhagen: Statens Pædagogiske Forsøgscenter, 1976.

Bengtsson, Jarl. "Centre for Educational Research and Innovation (2008), OECD's Centre for Educational Research and Innovation: 1968 to 2008." OECD, http:// www.oecd.org/site/educeri21st/40601796.pdf.

Brehony, Kevin. "A New Education for a New Era: The Contribution of the Conferences of the New Education Fellowship to the Disciplinary Field of Education, 1921-1938." Paedagogica Historica 40, nos. 5-6 (2004), 733-755.

Boyd, William and Muriel M. MacKenzie, eds. Towards a New Education: A Record and Synthesis of the Discussions on the New Psychology and Curriculum at the Fifth World Conference of the New Education Fellowship at Elsinore, Denmark, in August 1929. London: A.A. Knopf, 1930.

Christensen, Ivan Lind and Ydesen, Christian. "Routes of Knowledge: Towards a Methodological Framework for Tracing the Historical Impact of International Organizations." European Education 47, no. 3 (2015), 274-88.

Cowen, Robert. "Acting Comparatively upon the Educational World: Puzzles and Possibilities." Oxford Review of Education 32 (2006), 561-73.

"Den Frie Skoles Arbejdsprogram," Den Frie Skole 12, no. 3 (1938).

Dewey, John. "My Pedagogic Creed.” School Journal 54, no. 3 (1897), 77-80.

Dewey, John. Democracy and Education: An Introduction to the Philosophy of Education. New York: Courier Dover Publications, 2004 [1916].

Dewey, John. Experience \& Education. New York: Simon and Schuster, 2007 [1938].

Droux, Joelle. "Children and youth: A central cause in the circulatory mechanisms of the League of Nations (1919-1939)," Prospects 45, no. 1, 63-76.

Duedahl, Poul. Fra overmenneske til UNESCO-menneske: En begrebshistorisk analyse af overgangen fra et biologisk til et kulturelt forankret menneskesyn $i$ det 20. århundrede. PhD dissertation, Institut for Historie, Internationale Studier og Samfundsforhold Aalborg Universitet, 2007.

Henriksen, Spæt and Ellen Nørgaard. Vanløsedagbogen: En reformpædagogisk praksis (Copenhagen: Gyldendals pædagogiske bibliotek, 1983).

Elmersjö, Henrik Åström. “The Norden Associations and International Efforts to Change History Education, 1919-1970: International Organisations, Education, and Hegemonic Nationalism." Paedagogica Historica 51, no 6 (2015), 727-43.

Ensor, Beatrice. “Outlook Tower." The New Era 10, no. 37 (1929), 3-8.

Fuchs, Eckhardt. "History of Education beyond the Nation? Trends in Historical and Educational Scholarship." In Connecting Histories of Education: Transnational and Cross-Cultural Exchanges on (Post-)Colonial Education, edited by Barnita Bagchi, Eckhardt Fuchs, and Kate Rousmaniere, 11-26. New York: Berghahn Books, 2014.

Fuchs, Eckhardt. "The Creation of New International Networks in Education: The League of Nations and Educational Organizations in the 1920s," Paedagogica Historica 43, no. 2 (2007), 199-209.

Fuchs, Eckhardt. "Educational Sciences, Morality and Politics: International Educational Congresses in the Early Twentieth Century." Paedagogica Historica 40, no. 5 (2004), 757-84.

Gram-Skjoldager, Karen. Fred og folkeret: Dansk internationalistisk udenrigspolitik 1899-1939. Copenhagen: Museum Tusculanums Forlag, 2012. 
Haenggeli-Jenni, Beatrice. "Le rôle des femmes de la Ligue Internationale pour l'Education Nouvelle dans la circulation des savoirs pédagogiques (1920-1940)." In Les savoirs dans le champ éducatif: circulations, transformations, implémentations. Pour une histoire sociale de la fabrique internationale des savoirs en éducation 19e-20e siècles, edited by Joelle Droux and Rita Hofstetter (forthcoming).

Harris, Ian. "History of Peace Education." In Encyclopaedia of Peace Education, edited by Monisha Bajaj, 15-24. Charlotte, NC: Information Age Publishing, 2008.

Heater, Derek.

Hermon, Emily. "Peace Education Between the World Wars: A Historical Overview Of The Organized Transnational Peace Education Movement." Peace Research 19, no. 2 (1987).

Hemmer Egeberg, Olaf de. "Forsøgsarbejdets kaar i Danmark.” Den Frie Skole 4, no. 9 (1931), 139-41.

Jensen, Helge. "Arvin og skolen på La Coursvej." Poedagogisk-psykologisk tidsskrift (1950), 139-46.

Jensen, Niels Rosendal, "Kampen for enhedsskolen - forsøget på Emdrupborg." Arbejderhistorie 2, 1998, 45-59.

Jones, S. Shepard. The Scandinavian States and the League of Nations. London: Oxford University Press, 1939.

Kolasa, Jan. International Intellectual Cooperation: The League Experience and the Beginnings of UNESCO. Wroclaw, 1962

Krould, Harry J. and Helen F. Conover. Textbooks Their Examination and Improvement: A report on International and National Planning and Studies. Washington: The Library of Congress, 1948.

Lauwerys, Joseph A. History Textbooks and International Understanding: Towards World Understanding. Paris: UNESCO, 1953.

Livingstone, David. Putting Science in its Place: Geographies of Scientific Knowledge (Chicago: University of Chicago Press, 2003.

Moody, Zoe. “Transnational Treaties on Children's Rights: Norm Building and Circulation in the Twentieth Century." Paedagogica Historica 50, nos. 1-2 (2014), 151-64.

Nilsson, Ingela. Nationalism i fredens tjänst: Svenska skolornas fredsförening, fredsfostran och historieundervisning 1919-1939. Umeå: Umeå universitet, 2015.

Nielsen, J. "Denmark." Educational Yearbook of the International Institute of Teachers College. New York, 1936, 250-68.

Nygren, Thomas. "UNESCO and Council of Europe Guidelines, and History Education in Sweden, c. 1960-2002." Education Inquiry 2, no. 1 (2011), 37-60.

Nørgaard, Ellen. "Skolebogsbetænkningens historieafsnit: Dets tilblivelseshistorie og træk af dets modtagelse." Årbog for dansk skole-historie (1970), 89-106.

Nørgaard, Ellen. Lille barn, hvis er du? En skolehistorisk undersøgelse over reformbestrobelser inden for den danske folkeskole i mellemkrigstiden. Copenhagen: Gyldendals Pædagogiske Bibliotek, 1977.

Nørvig, Anne Marie. "Vor skoles struktur er ikke tidssvarende," Land og folk, August 14, 1948.

Parshuram, Mendhekar Dattatrya, "Education for Peace." Indian Streams Research Journal 3, no. II (2013). 
Popkewitz, Thomas S. ed. Rethinking the History of Education: Transnational Perspectives on its Questions, Methods, and Knowledge, New York: Palgrave Macmillan 2013.

Poulsen, Jørgen Egedal. "Forsøgscentrets første år." In Beskrivelse og indføring i lokalarkivet. Copenhagen: Statens Pædagogiske Forsøgscenter, 1993.

Read, Herbert. Education for Peace. New York: Charles Scribner's, 1949.

Rifbjerg, Sofie. Treek af den moderne opdragelseshistorie. Copenhagen: Gyldendal, 1966.

Sadler, Michael. "Introduction." In Towards a New Education: A Record and Synthesis of the Discussions on the New Psychology and Curriculum at the Fifth World Conference of the New Education Fellowship at Elsinore, Denmark, in August 1929, edited by William Boyd and Muriel M. MacKenzie. London: A.A. Knopf, 1930.

Simonsen, S. "A Dalton Plan Experiment in Denmark." The New Era 10, no. 37 (1929).

Sobe, Noah, W. "Entanglement and Transnationalism in the History of American Education." In Rethinking the History of Education: Transnational Perspectives on its Questions, Methods, and Knowledge, edited by Thomas S. Popkewitz, 93-107. New York: Palgrave Macmillan, 2013.

Suhr, Laurits. “Arbejdsskolen." Vor Ungdom (1923), 158-65.

Undervisningsministeriet. "Undervisningsvejledning for Folkeskolen." Betænkning no. 253 (1960).

Watras, Joseph. "The New Education Fellowship and UNESCO's Programme of Fundamental Education." Paedagogica Historica 47, no. 1-2 (2011), 191-205.

White, Margaret. "The New Education Fellowship: An international community of practice." New Era in Education 82, no. 3 (2001), 71-75.

Ydesen, Christian. The Rise of High-Stakes Educational Testing in Denmark, 19201970. Frankfurt: Peter Lang Verlag, 2011.

Ziliacus, Laurin. "Den nye opdragelse af idag." Den Frie Skole 12, no. 1 (1939), 3-8. 